\title{
UCAREO AND THE ESCORIAL ${ }^{1}$
}

\author{
B Y \\ GEORGE KUBLER
}

EXICO has often endowed Spain with gifts that were ill acknowledged.
In the sphere of a jealously-mationalized artistic production, mo-
reover, the mother-country's expressions of gratitude to the daughter have
been few. Thus it is not an easy matter to trace the transmission of various
cultural goods from America to the Peninsula. Foreigners have oc-
casionally pointed to the debts. Otto Schubert 2 indicated several years ago
that Andalusian art, notably in the Cartuja of Granada, owes much of
its high artistic discipline to "Indo-Mexican" stimuli. It should also be
possible to demonstrate a transfer of the principle of the "open chapel" to
Peninsular architecture, specially at the Escorial itself. 3 That task, how-
ever, I shall reserve for another essay.
It is the object of this paper to suggest still another possible bor-
rowing by Spain from Mexico, in the construction of the Escorial. The
loan is one of greater significance than the supply of tropical woods that
Mexico ftrnished. It involves a highly-specialized technique of construction.
I shall try to show that in the decade $1550-1560$, an obscure Augustinian
friar named Juan de Utrera devised a method of accelerated and econo- 
mical construction at Ucareo in the bishopric of Michoacan, and that this method later became critically important in Juan de Herrera's reorganization of the Escorial quarries, after 1576. It is possible to propose a historical connection between the two events. I shall begin with a review of happenings at the Escorial.

In 1572, the Escorial had been under construction for virtually ten years. 4 Philip's project of building the gigantic mausoleum requested by Charles $V$ had been in realization since 1554; the site was chosen in 1561, by a learned commission acting according to the precepts of Vitruvius, and the first stone was laid on April 23, 1563, after a two-year interval of planning and defiberntons. But by $: 1572$, f relatively fule had been achieved. The foundations for the chief element of the vast complex, the basilica itself, had not been laid. Most of the northern half of the gridiron plan was still in foundations, and the facades of the Patio de los Reyes remained half-built (Fig. 1). Progress had been greatly impeded by the death in 1567 of the first architect, Juan Bautista de Toledo. Toledo had established the ground plans for the Esforial bu his design was criticized by an Italian authority as being naive and crude. 5 Juan de Herrera, Toledo's assistant, was placed in charge after his master's death, only to be frustrated in the discovery that Toledo had left no plans for the execution of the roofs of the structure. 6 Thus, in 1572, energetic measures were taken to hasten the rate of advance. On October 22 of that year; an extraordinary royal Instruccion, framed by Herrera was issued for the condact of the enterprise This document consist of 52 articles relating to the organization of labor, its supervision iand ispection, and many other matters, such as the wage scale. ? It is anique among records of Renaissance building activity, for the extraordinary; bureatucratic detaik and the paternalistic attitude towards labor: One section is of special interest, and it pertains to the duties of the apanejadores de canteria: ,

"Para que haya más orden y menos costa en ta saca de piedras de las. canteras, tecorterán los aparejadores del oficio aquéllas, dando relación de las piedras sacadas y tanteando su utilidad.' prótorando que sean de las thás cétcanas

$\because \because, \quad y$ advirtiendo a las persomas encargadas de ellas tael tamaño y olidad de las: piedras que fuere menester pata te clección. dando el contramolde de las piezas. con la demasia y rentaja que se requiere para que con menos trabajo y costa

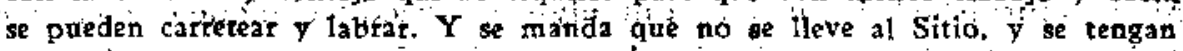

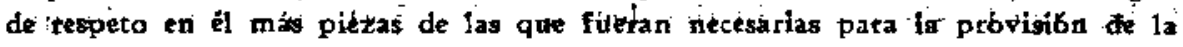
vit. obra", 
In other words, as early as 1572 , an effort was made to rationalize the supply system, and to establish some method that would reduce wastes of time and labor at the quarries. The mention of contra-moldes implies some use of predetermined patterns and measures for laying out the work.

Two years later, in 1574, the foundations for the basilica were begun, but no revision of the working organization seems to have occurred at that time. In 1576 , however, on January 9, an important new order was issued to have all stones cut and trimmed at the quarry, rather thin in situ at the scaffolds. 8. This major reform suggests some reliance upon the methods previously divised by Fray' Juan' de Utrera at Ucareo. The complexity of the undertaking at the Escorial had made it essential to restrict confusion at the building site. The decision to localize all stone cutting at the quarries came directly from Herrera, subject to royal approval. 'His proposal was opposed by. a strong faction including the master craftsmen in each guild, and Fray Villacastin, the Jeronymite obrero mayor. 9 Herrera was supported by the Prior and by the destajeros. The opposition argued that the distance of the quarries from the scaffolds made the project impracticable; that the finished stones would be damaged in transit, and that it would be impossible properly to feed and equip the army of stoneworkers at the quarries.

Herrera's notion appears to have struck the conservatives with all the impact of a radical reform. The Asturian architect cited ancient authority for his plan, and invited Philip II to arbitrate the question. According to Villacastin, who absented himself from the trial, the King then examined both modes of work in great detail, and decided in favor of the Herreran method, in view of the great economies of time it made possible. From that day on, construction moved at an extraordinary rate of speed. The basilica was completed in 1582, and the last stone of the complex was laid on September 13, 1584.

Herrera later claimed, in 1584, that his method had reduced costs by one half or more, and that he had completed in eight years that which would have taken eighty years to build in the old way. 10 The new organization of labor was repeated immediately, moreover, at Aranjuez, beginning in 1584.11 In brief, a preliminary reorganization had been initiated in 1572; a rational and systematic division of labor was effected: in 1576, and thereafter became a normal mode for spanish construction. 
Herrera was not the first to use this technique, nor, strictly speaking, was it his invehtion. On the contrary, an identical system had been used in New Spain almost a full generation earlier. At Ucareo, not far from Acámbaro in Guanajuato, the Augustinians had founded a convento among the scattered sierra Indians sometime between 1554 and 1557, during the Provincialate of Fray Diego de Vertavillo. 12 .The building history of this establishment is of extraordinary. interest: The first prior to be appointed was Fray Juan de Utrera, whom Basalenque qualified as a "muy grande arquitecto", who endeavored to build, not "conforme el puesto merecía, sino conforme su arte le dictava". 13 According to Basalenque, Utrera had already laid the foundations for an imposing structure in the remote mountain village, when the project came to the ears of Viceroy. Luis de Velasco, who ordered the Augustinian Provincial to have the enterprise restricted. The Provincial complied by visiting the site, and Utrera was persuaded to spend no longer than one year 14 in the construction of his establishment.

Utrera, however, had already ("como diestro arquitecto", in Basalenque"s phrase) arranged to have all stone cut to its final form at the quarries.

The lumber was likewise to be finished at the yards. Thousands of workmen, according to Basalenque, were thus employed, and ro sound of work was heard on the scaffolds. By these means, Utrera achieved a seven years labor in once. The size of the completed buildings horrified the Provincial at the time of bis next visit (Fig. 2, 3). Among other conveniences, the edifice contained a large subterranean water storage tank, to which a flight of stairs gave access. In 1673, Basalenque was impressed by the strength and finish of the work. 15

That Herrera was not the first architect in the sixteenth century thus to analyze the process of supply is beyond question. It is likely, furthermore, that Herrera knew directly of Utrera's technique. The connection may be found in the Spanish voyage of Fray Aloniso de la Veracruz, the crudite theologian and administrator of the Auguistinian Order in New Spain. 16. In 1571, Fray Alonso occupied a critically important post in Madrid as Prior of the monastery of San Felipe el Real, and as $V$ isitador and Reformador of the corrvental establishments of the Kingdon1 of Toledo. He was so highly regarded by :Philip If that he whs requested to serve as general Commissioner in Madrid for the Augustinians. in America. Fray Alonso did not accept the post, and later returned to 
his ustual duties in Mexico. 17 But it is clear that Philip was acquainted with the friar. More than ever, the King's dominant concern was with architecture in those years, and specially so in 1571, a critical time in the history of his obsession, the Escorial... It is probable that Fray Alonso informed His Majesty of the singular architectural performance at Ucareo, for the Augustinian was also deeply concerned with building problems. Under his direction, the first extensive building campaign of the Augustinians in New Spain was initiated after the pest of 1543. 18 The final link in the transmission involves Philip's close relations with Herrera, which are too well known for repetition here.

It would be wild exaggeration to insist that Herrera was exclusively dependent upon a knowledge of Utrera's method. On the contrary, Herrera was certainly acquainted with Palladio's views upon the subject. The Italian work was putblished in 1570 , and although it is curious that no manuscript or printed copy of the book was found in Herrera's library in 1597, Herrera did insist; while defending his plan in 1576, that his system was the forgotten method of the ancients. Palladio gave no more than a faint suggestion of the technique of stonecutting prior to construction, in chapter $\mathrm{X}$ of Book One, entitled $D e$ modo che tenevano gli antichi nel far gli edifici di pietra, but Palladio's allusions are far from being specific. 19

Another text that was surely known to both Utrera and Herrera is the Oid Testament description of the building of the Temple of Solomon (Kings $I, v, 15 ; \mathrm{vi}, 7$ ) :

\footnotetext{
"Solomon had threescore and ten thousand that bare burdens. and fours. core thousand hewers in the mountains... and the house. when it was in building, was built of stone made ready before it was brought thither so that there was neither hammer, nor axe. nor any tool of iron, heard in the house while it was building".
}

Basalenque says that Utrera was following Biblical example. In the case of the Escorial, it is patent over and over again that Philip II wished to identify himself with the builder-kings of the Old Testament. Thus the colossal figures by Monegro on the facade of the basilica within the Patio de los Reyes, represent Biblical builders. Later of course, the project for the Temple of Solomon, by Francisco de Villalpando, was based upon the tangible proportions of the Escorial itself. 20 
Thus a whole complex of factors led to Herrera's decision to reorganize the construction methods of the Escorial. Among these factors, if the historical connection be admitted, the American experiment at Ucareo should be interpreted as the decisive element, providing a working scheme easily adapted to more ambitious undertakings.

The significance of this minate connection would tot trivial unless it formed one more aspect of a relationship that appears to prevail between Europe and historic America. The New World has again and again provided the pragmatic solutions to problems in Europear theory. In Eurdpe, at this time, very few towns were created, and the speculations of! suich early urbanists as Filarete, Alberti, and-Jinancesco di Giorgio Martini remained on paper until their realization was approximated in Ameriça. The conversion of abstraction into tri-dimensional ppace characterized the urban foundations of the sixteenth century in New Spain nimilarly, the jdeal society of. Saint Thomas More found its material garment in the work of Bishop Quiroga, and the social theory of the Jesuits was realized only in Paraguay. The polfitical institutions of modern America, given reality by the declarations of the decade of the 1770's in North America, are the first pragmatic manifestations of a concept of human worth and dignity that had been agitating men's minds since the foundation of Christianity. Thus the relationship between Ucareo and the Escorial constitutes a minute phase of the immensely complex and poorly-studied problem of American historical constants.

\section{$\begin{array}{lllll}\mathbf{N} & \mathcal{O} & \mathbf{T} & \mathbf{E} & \mathbf{S}\end{array}$}

1 Much of the material for this atticle was gathered during a visit to Mexico which was made possible by a travel grant from the American Council of Learned Societies in 1941 .

2 Schnbert, Otto, Gexahichte det Barock in Spanien, Estlingen: 1908. Mhiguel Soli. Historia del ate ficpanoamericano, Barcelona: $1935, p, 189$, bat show a that the famous mancerina porcelain and silver owes its Spaniş yogue to a Viceroy of Peru, Marqués de la Mancera the seventeenth viceroy of Pera, in office from $1639-$ 1648); who brought it with him from South America.

' 3 Set Rafael Garía Granados, Capillos de indios en Núvo Españop: Archivo español de arte y arqueología, XXXt (1935), 3-27. 
4. The literature of the Escotial is most extersive. A few important soncess and articles may be cited here: Josć Quevedo; Historia del real monasterio del Escarial, Madrid: 1849. Fray Francisco de los Santós, Descripción del real monasterio de Sờ Lotenzo del Etrotial. Unice maxavilla del murido, first edition 1657. 'frequently' teprinted. Jean Babelon; Jacopo de Trezzo ta construction de l'Escoriat: essai sur les arts à la cout de Philippe II, 1519-1589. Bordeadx: 1922. L. Bertrand, Philippe II i l'Escorial Paris: 1929. Agustin Rujz de: Arcạute, Jaan de Herserd, Madrid: 1936. Paul Guinard, Madrid, l'Escorial et les apciennes rápidences royales, Paris: 1935.

5 Paciottits report is given in Spaniph in Ruiz de, Areaute, op. cit., Appendix I, p. 147 .

6 Antonio Ponz, Viaje de España, Madrid: 1772-94, vol. IX, p. 175.

7 The full text is to be found in E. Llaguno y Amirola and $A$. Ceán Bermúdez. Noticias de los arquitectos. ., Madrid: 1829, vol. II, pp. $291 \mathrm{ff}$.

8 At the same time, 60 additional master quarrymen were assembled. Twenty destajeros were chosen, and each was assigned a crew of forty stoneworkers. See Bertrand, op. cit., p. 142. Schubert notes an early manifestation of the industrial principle of the division of labor. Schubert, op. cit., p. 56.

9 The texts for the controversy may be found in Llaguno y Amirola, op. cit., vol. 1I, pp. $124 f f, 311$.

10 Ponz, op. cit., vol. IX. p. 279.

11 Llaguno y Amirola, op. cit., vol. 1I, p. 279.

12 Grijajষa, Crónica de le orden de N.P.S. Agustín en... Nueva España 2nd, edition. Mexico: 1924, p. 273. Romero, Noticias... del obispado de Michoecán, Mexico: 1862, p. 63 . gives 1565 .

13 Basalenque, Historia de la provincia de S. Nicolás de Tolentino de Michoacón, Mexico: 1673, p. 69.

14 Efforts had already been made to restrict the duration of building operations elsewhere in New Spain. See Ricard, La 'conquête spirituelte' du Mexique, Patis: 1933, p. 100.

15 Basalenque, op. cit., p. 70. Ricard. op. cit., pp. 205-6. The chnrch at Ucareo was not built until the end of the sixteenth century. Before that time, masses were said if a jacal near the convento. Basalenque, op. cit., pp. 70. 124. 147. At the present time the convento remains intact only on the ground floor. The npper story has been destroyed, and many rooms of the ground flooe no longer exist, although the water tank is still in use.

16 Biographical notes on Fray Alonso are found in Basalenque, op. cit., pp. 35-39; García Icazbalceta, Obras completas, vol. III, p. 46. Information on his Spanish voyage is in Escobar, American Thebrida, Mexico: 1924. p. 337.

17 The docament was published by R. Ricard, Fray Alonso de la Vera Cruz. Un documento desconocido en México', Abside, II (1938), NQ 1, pp. 22-4. ". . Por la satisfacción que tenemos de las letras, suficiencia, bondad y rrecogimiento del Maestro Fray Alonso de la Vera Cruz, prior de! monasterio de San Felipe desta villa de Madrid, e inteligencia que tiene de las cosas de aquellas partes del tiempo que residió 
en 12 Nueva España, nos ba parecido les hera bien y podzí informar de cosas espiritzales de aquellas partes... asi o* ruego.... le nombrax y enńalar por procurador $y$ comisario general de low conventos de vuettra Orden de las dichue nuentras Yadias. parz que resida de ordinasio en exta nuestra Corte en los negocios toeantes a ellos..." Philip II to the General of the Augustinian Order. October 27, 1571, at Madrid. 18 Grijzlva, op. cit., p. 271.

19 Palladio, 1 quattro libri dellearchirettura, Venice: 1570. The catalogive of Herrete's libsary is printed in Raiz de Areante, op. cit., p. 150.

20 Villalpando, F. de, In Ezechititim explanationts..., Rome: 1596-1604. 


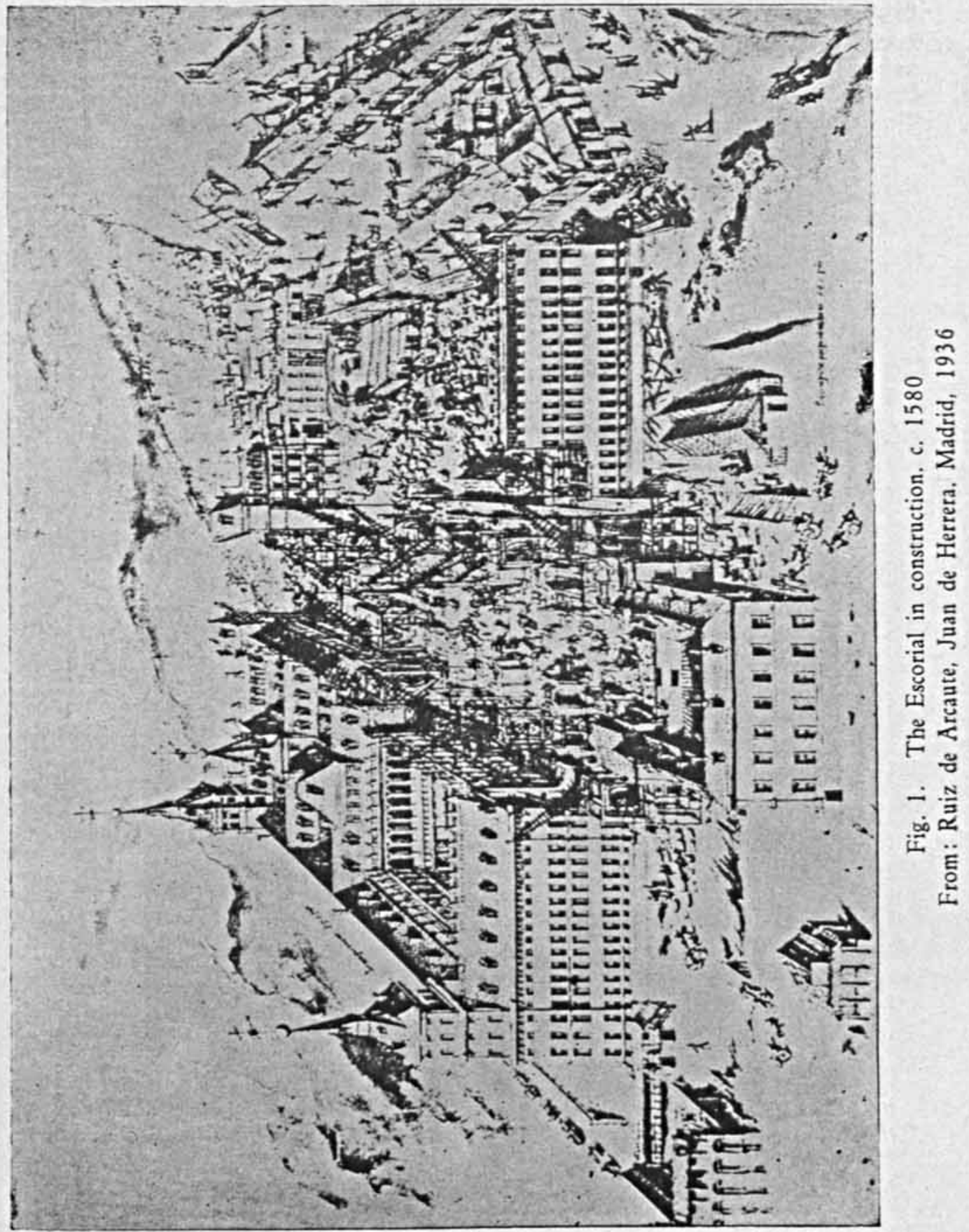


DOI: http://dx.doi.org/10.22201/iie.18703062e.1942.8.289

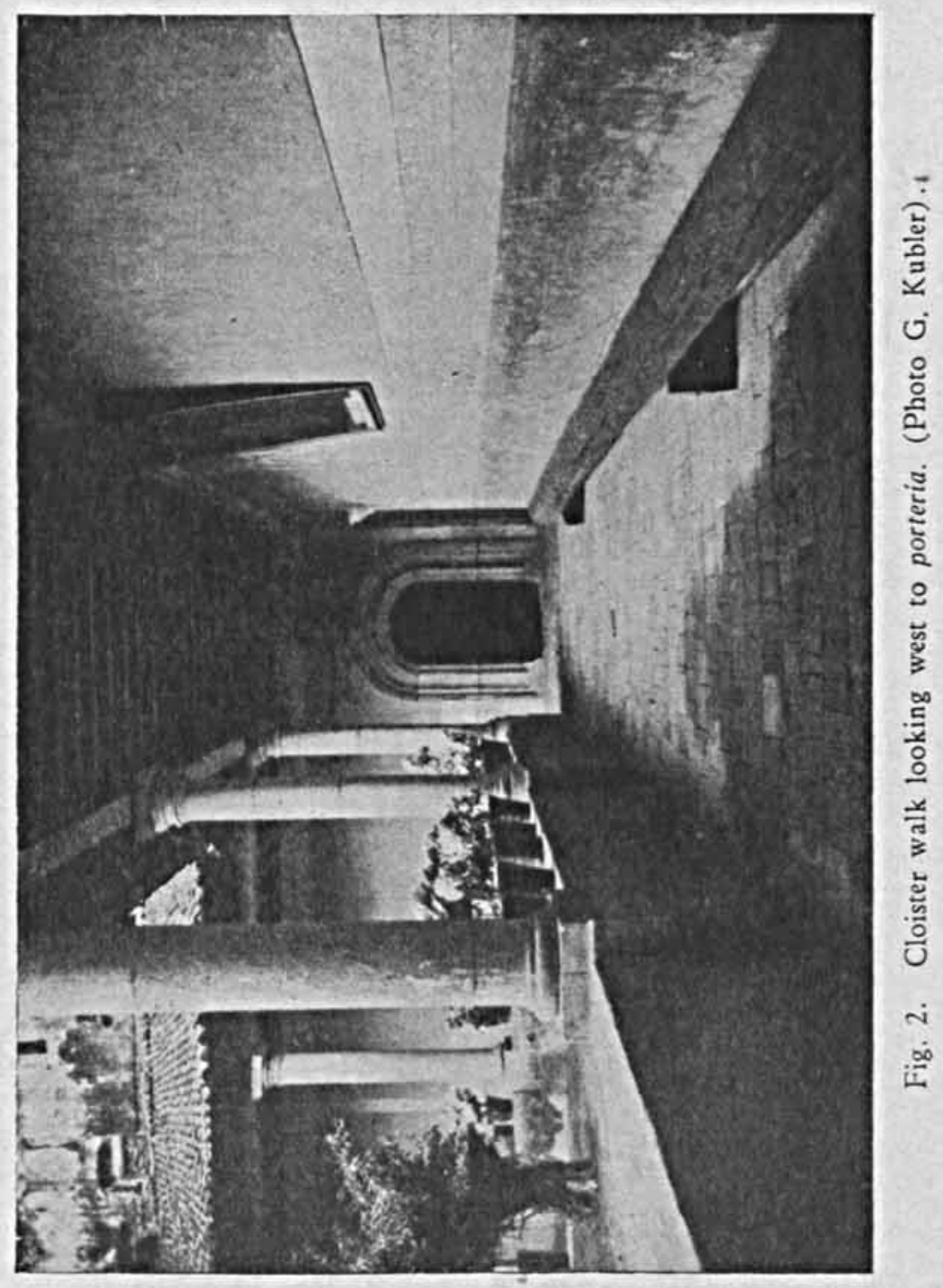


DOI: http://dx.doi.org/10.22201/iie.18703062e.1942.8.289

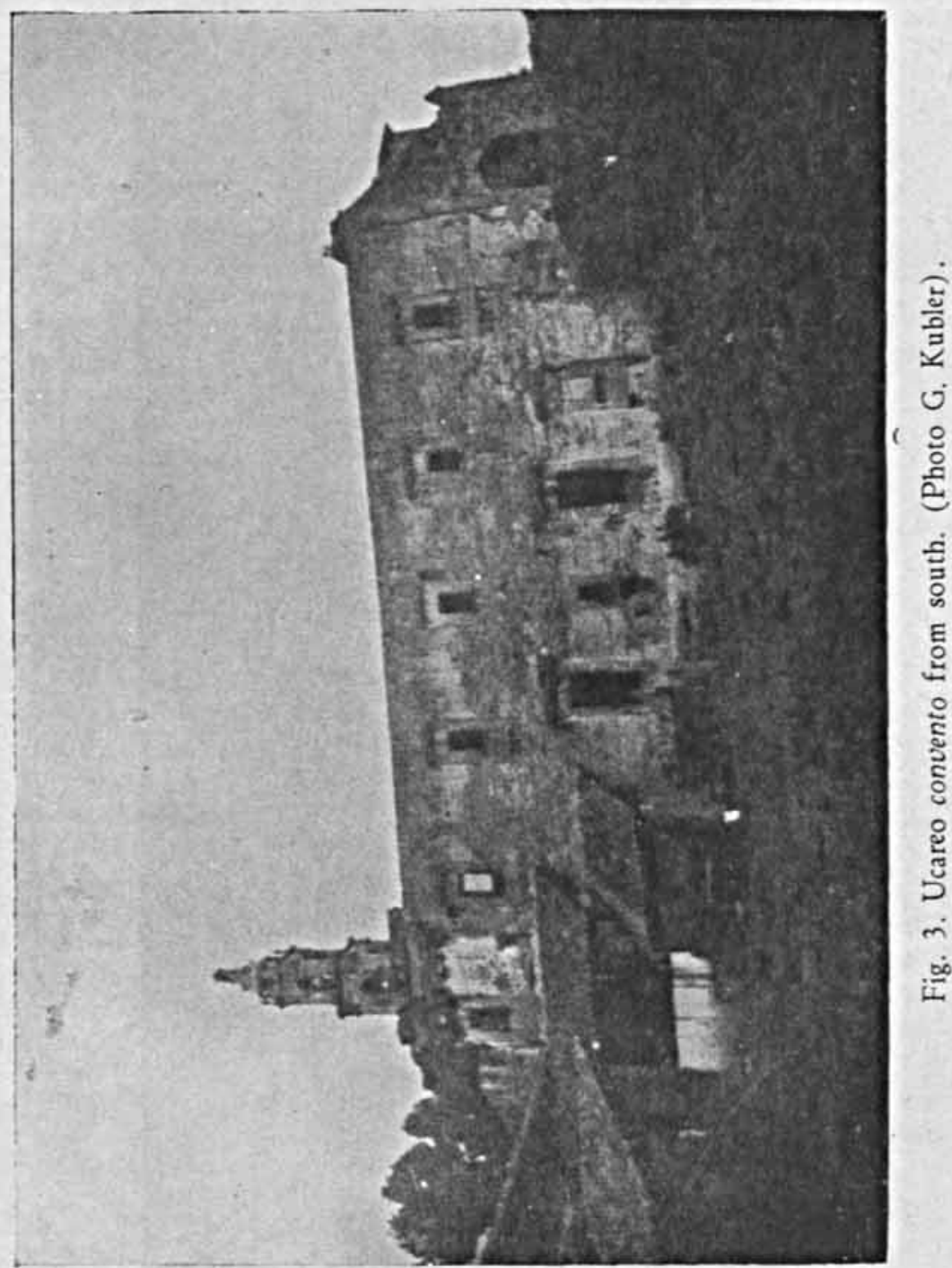


DOI: http://dx.doi.org/10.22201/iie.18703062e.1942.8.289

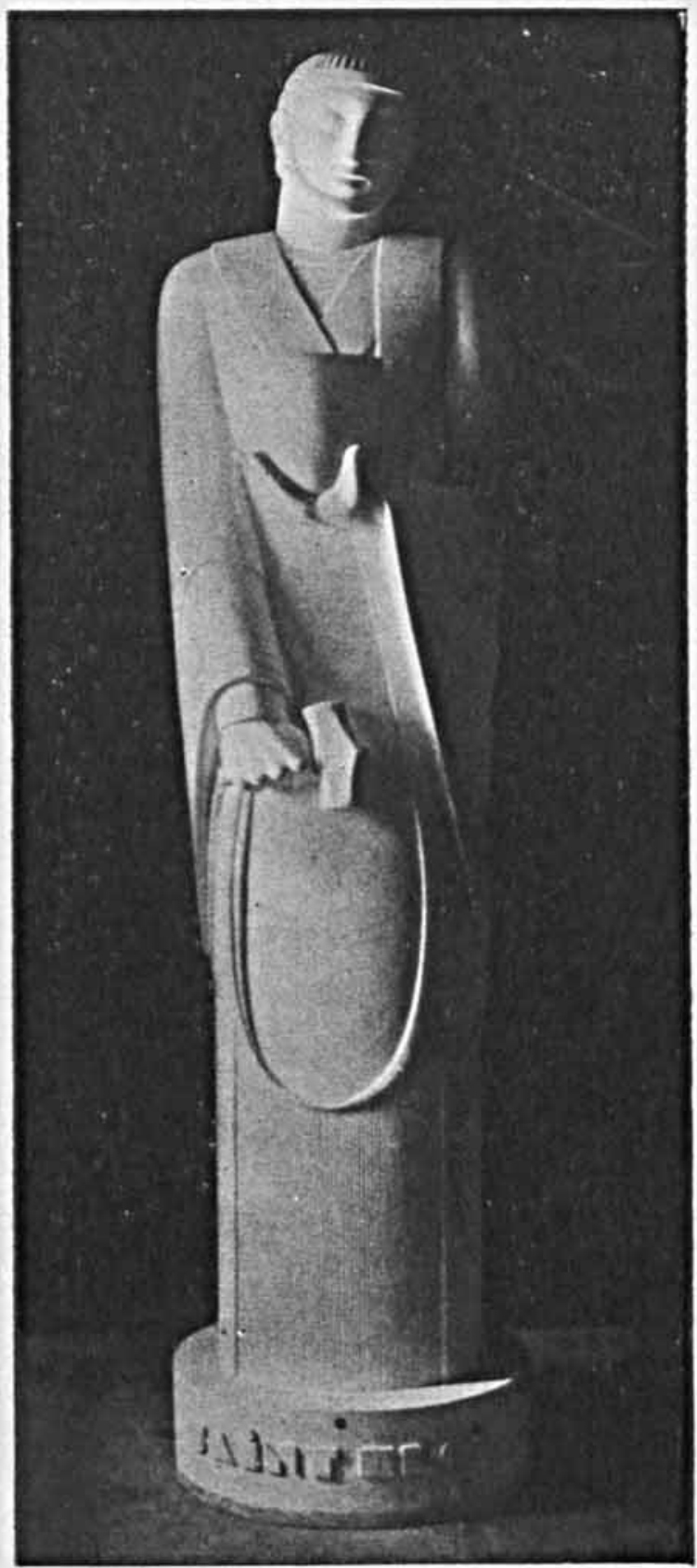

San Eligio, patrón de los plateros. Obra de J. E. Puigforcat 